\title{
The Role of Curriculum: Conservative, Critical and Evaluative, and Creative
}

\author{
Shella Es Shabarina \\ Department of Educational Management \\ Universitas Negeri Malang, Indonesia \\ shellashab96@gmail.com
}

\author{
Wajihatul Aniqoh \\ Department of Educational Management \\ Universitas Negeri Malang, Indonesia \\ wajihatul@gmail.com
}

\author{
Mustiningsih \\ Department of Educational Administration \\ Universitas Negeri Malang, Indonesia \\ mustiningsih.fip@um.ac.id
}

\begin{abstract}
Curriculum is guidelines for the implementation of learning process. It is compiled by the government. Curriculum has changed and developed from time to time. This research is aim to know the role of curriculum in conservative, critical and evaluative, dan creative ways in school. This research used qualitative descriptive method. The result of this research is SDN 01 Kauman applied curriculum 1947, 1952, 1964, 1968, 1975/1976, 1984, 1994, 2004 (KBK), KTSP 2006, and 2013. In applying 2013 curriculum, the school faced difficulty in assessing aspect. The school found a solution by creating an application to make assessing process easier.
\end{abstract}

Keywords: curriculum, the role of curriculum

\section{INTRODUCTION}

Education is a learning process of knowledge and skills done by consciously effort and programmed. Education is a human right and must. Education starts since individual was born to the time; they reach an adult. Education since individual was born given by parents and people around them with informal situation and happen anywhere and anytime. Formal education is obtained at school when individual is 7-year-old. The purpose of education is to increase knowledge that can be applied in everyday life.

School is an institution as a facilitator in providing education program for people. In school, individual facilitated with knowledge, development of self-competence, development of skill, facilities and infrastructure that can help individual increase their competence and skill, etc. Learning situation in school is formal where individual spends most of the time at class when the transfer of knowledge happens. The knowledge of academic and non-academic that given by school based on compiled guidelines by the government, which is curriculum.

Curriculum born and used as learning guidelines since 1947, where that was the first curriculum Indonesia has made. With the development of time, curriculum was evaluated to be changed or developed. Curriculum was designed in such way to achieve targets that align with the goals of education.

Curriculum can also be called as guidelines in learning process. Curriculum arranges the content of material or knowledge, methods, and learning procedures. With the development of time, evaluation of curriculum development is needed in aim to provide education in accordance with development standards. With the development of time, demands, needs, and facilitations have increased. Curriculum hoped can form and give education to students in accordance to development of time. Students who given preparations and knowledge can contribute in society and state.

Juridical foundation is a main foundation in curriculum improvement in Indonesia. Pancasila and
UUD 1945 are references to develop national curriculum, differences in curriculums lie in education goals and approaching in implementation of curriculum. Curriculums that has been enforced in Indonesia are learning plan 1947, 1952 curriculum, 1965 curriculum, 1968 curriculum, 1975-1976 curriculum, 1984 curriculum, 1994 curriculum, Curriculum Based on Competence (CBC/KBK) in 2004, 2006 (KTSP), and 2013 curriculum.

\section{METHOD}

The approaching in this research was a study case with qualitative descriptive. Qualitative research is a form of social action which is trying to understand or interpret people's experience in aim to understand the reality they've faced or the information they've given (Mohajan, 2018). In another mean, qualitative research is to learn something in natural setting, try to give understanding, or interpreting the meaning of phenomenon from people. Qualitative research is describing the meaning of data that researchers got with showing the evidence. In qualitative research, the participation and interaction of researchers were a key to success. The technique in this research were interview, observation, and documentation.

\section{RESULT}

SDN 01 Kauman stand since 1910. The school has implemented curriculum from time to time. The curriculums were: 1947 curriculum, this curriculum contained two main things used as guidelines for school. First, subject lists dan the schedule. Second, teaching outline. 1952 curriculum, this curriculum did not have many different as 1947 curriculum but in every subject, it was more detail and had plans and content, that had to be connected to everyday life. Each teacher had to teach one subject. 1964 curriculum, the subject was classification into five fields of study: moral, intelligence, emotional/artistic, skill, and physical. Elementary education was more emphasize to knowledge and practice functional activity. 
1968 curriculum, there were changes in education curriculum structure into Pancasila soul building, basic knowledge, and special competence. $1975 / 1976$ curriculum, emphasized in goals to make education more efficient and effective. Method, subject, and goal of teaching specified in Instructional System of Development Procedure (ISDP/PPSI). 1984 curriculum, carried process skill approach. Student position was learning subject. From observing something, grouping, discussing, and reporting. This model called Way of Learn Active Student (WLAS/CBSA). 1994 curriculum, there was change to the system of time which was changing from semester system to quarterly system.

2004 curriculum (KBK), education based on competence, prioritized on development of competence to do tasks as performance standard. KTSP 2006, used legislation as policy foundation. The content included subject, competence level to achieve competency of graduate on level and kind of education. In content standard contained: basic skeleton, curriculum structure, Competence Standard (CK/SK), and Basic Competence $(\mathrm{BC} / \mathrm{KD})$ in each subject on each semester from any kind and level of elementary school and secondary school. 2013 curriculum, SDN 01 Kauman is currently using this curriculum where researchers dig more information about the role of curriculum at the school a conservative, critical and evaluative, and creative. The result showed that school had difficulty in applying the 2013 curriculum. The main problem was the assessing process or system.

\section{DISCUSSION}

According to Hamalik (1990), there are three curriculum roles that are considered very important, namely conservative roles, creative roles, and critical / evaluative roles. Thus, conservative role essentially places a curriculum oriented to the past. This role becomes very basic in nature, adapted to the fact that education is essentially a social process, which one of the educational tasks, which is to influence and foster student behavior in accordance with the social values that live in the community.

Conservative is an attitude that tries to maintain a state or conservative, or follow the prevailing tradition (Helvira, Hasanuddin, \& Nurizzati, 2013). SDN 01 Kauman always tries to run a government program regarding the renewal of the established curriculum even though in reality, according to the school, the 2013 curriculum is considered very different from the previous curriculum which is difficult to apply to learning, seen from the aspects assessed namely the previous curriculum put more emphasis on academically compared to skills, $60 \%$ are academic and $40 \%$ are skills. While in the 2013 curriculum, assessment emphasizes $40 \%$ academically and $60 \%$ skills but the assessment format is judged differently from before.

Given this, the school did not apply the 2013 curriculum directly at all levels of the school but gradually. In 2013 the 2013 curriculum was only applied to grades one and four. In 2014 the 2013 curriculum was applied to grades two and five. In 2015 the 2013 curriculum was applied to classes three and six. In the end in 2016 all grade levels have implemented the 2013 curriculum as a learning reference.
Critical and evaluative is the role of the curriculum used to assess and choose what will be applied (Fajriyah, Huda, \& Arifin, 2018). This role is motivated by the fact that the values and culture that lives in society are constantly changing so that the inheritance of past values and culture to students needs to be adjusted to the conditions that occur in the present. In addition, developments that occur in the present and the future are not necessarily in accordance with what is needed by students. Therefore, the role of the curriculum is not only to inherit existing values and culture or apply the results of new developments that occur, but also has a role to assess and choose the values and culture and new knowledge to be inherited. In this case, the curriculum has a role as a control or social filter. Social values that are no longer in accordance with the conditions and demands of the present are removed and modifications or improvements are made.

SDN 01 Kauman critically provides evaluations on student report cards (report cards). The report card assessment format from the center is considered quite confusing because it only uses descriptive assessments without numbers to be used as a benchmark for children's abilities. This makes parents question the extent of the child's ability in academia because it is considered less representative.

Creative is creating activities that are creative in accordance with the development and needs of students and society (Fajriyah, Huda, \& Arifin, 2018). The creative role emphasizes that the curriculum must be able to develop something new in accordance with the developments that occur and the needs of society in the present and future. The curriculum must contain things that can help each student develop all the potential that exists in him to obtain new knowledge, new abilities, and new ways of thinking needed in his life. Society in the present and future. Creative Role The curriculum plays a role in carrying out various creative and constructive activities, in the sense of creating and compiling a new thing in accordance with the needs of the community in the future. SDN 01 Kauman tried to find a solution to facilitate the assessment. The school follows the workshop with the education office in order to get a more detailed explanation and insight about the assessment system expected by the center. Then the school held a discussion with another school to find a solution in the meeting. In the end, SDN 01 Kauman made a report card application that could make it easier in pre-existing assessments, such as those being prepared by teachers and before, excluding clear numbers and results. Assessment is done by entering the value of student data and descriptive reviews about students.

In addition, the school also develops student activities to improve skills by once a month doing entrepreneurial activities where the products sold are the result of the students' skills. The activity is carried out in accordance with the theme book, for example like, if the theme book discusses about plants that can be used as medicine then students are required to process these plants into medicines such as sinom, saffron tamarind, and others. The results were exhibited in the school's bazaar activities which were attended by students, teachers and school staff. 


\section{CONCLUSION}

Education is an obligation and a right for all people. Education starts from birth to adulthood. Birth education is given by parents and people around them with non-formal situations and happens anywhere and anytime. The curriculum emerged and was used as a guide to the learning process since 1947, which is the first curriculum in Indonesia. Along with the times, the curriculum is evaluated to be changed or developed in accordance with the times. The curriculum has been designed in such a way, in order to realize the achievement of the expected target in accordance with educational goals.

Juridical foundation is the main foundation in improving the curriculum in Indonesia. The juridical foundation of Pancasila and the 1945 Constitution is as a reference for developing the national curriculum. The curriculum implemented in Indonesia has undergone many updates, namely: 1947 lesson plans, 1952 curriculum, 1964 curriculum, 1968 curriculum, 1975/1976 curriculum, 1984 curriculum, 1994 curriculum, competency-based curriculum (KBK) in 2004 and 2006 KTSP, and 2013 curriculum. There are three curriculum roles that are considered very important, namely conservative roles, creative roles, and critical / evaluative roles.

\section{REFFERENCE}

[1] Arifin, Z. 2014. Konsep dan Model Pengembangan Kurikulum. Bandung: PT Remaja Rosdakarya Offset.

[2] Fajriyah, Huda, M. A. Y., \& Arifin, I. 2018. Implementasi Kurikulum Kulliyatul Mu'alimin al-Islamiyah di Pondok Pesantren Tarbiyatul Mu'allimien Al'islamiyah (TMI) alAmien Prenduan dan Ma'hadul Mu'allimien al-Islamiyah (MMI) Mathlabul Ulum Jambu Sumenep. Malang: Universitas Negeri Malang.

[3] Helvira, Hasanuddin, WS., \& Nurizzati. 2013. Konservatif dan Progresif Spiritualisme dalam Novel Bilangan FU Karya Ayu Utami. Padang: FBS Universitas Negeri Padang.

[4] Hidayat, S. 2015. Pengembangan Kurikulum Baru. Bandung: PT Remaja Rosdakarya Offset.

[5] Mulyasa, E. 2014. Pengembangan dan Implementsi Kurikulum 2013. Bandung: PT Remaja Rosdakarya Offset.

[6] Mohajan, H. 2018. Qualitative Research Methodology in Social and Related Subjects. Journal of Economic Development, Enviroment and People, 7(1), 23-48.

[7] Oemar, H. 2009. Dasar-dasar Pengembangan Kurikulum. Bandung: PT Remaja Rosdakarya.

[8] Wiranto, D. 2014. Perspektif Historis Transformasi Kurikulum di Indonesia. Jakarta: SBC.

[9] Zaini, H. 2015. Karakteristik Kurikulum 2013 dan Kurikulum Tingkat Satuan Pendidikan (KTSP). Eldare: Jurnal Manajemen Pendidikan Islam, 1(1), 15-31. 